\title{
STRATEGI PEMULIHAN KEPARIWISATAAN KOTA PEKALONGAN PADA MASA ADAPTASI KEBIASAAN BARU
}

\author{
Hartati $^{1)}$, Choliq Sabana ${ }^{2)}$, Moh. Projo Angkasa ${ }^{3)}$, Sobrotul Imtikhanah ${ }^{4)}$, Ahmad Syakir Kurnia ${ }^{5)}$ \\ 1,2,3,4,5 Dewan Riset Daerah (DRD) Kota Pekalongan \\ ${ }^{1,3}$ Poltekkes Kemenkes Semarang \\ ${ }^{2}$ Universitas Pekalongan \\ ${ }^{4}$ Universitas Muhammadiyah Pekajangan Pekalongan \\ ${ }^{5}$ Universitas Diponegoro \\ Email: ${ }^{1}$ hartatilana@gmail.com
}

\begin{abstract}
The presence of COVID-19 as a pandemic, determined by WHO, has destroyed all activities in society, including the people of Pekalongan city. The Covid-19 virus, which initially had an impact on the health sector, it immediately turned out to also have a domino effect on other sectors, such as the economic, as well as the social one; including the tourism. Restrictions on human movement from one place to another, prohibition of crowding and avoiding crowds make tourist objects deserted by visitors. Considering this pandemic is not known when it will end, and then all parties must prepare themselves with a new custom adaptation order. Of course, it requires the readiness of all parties, both local governments and tourism actors in Pekalongan City. This study is a qualitative descriptive, and data collection is taken by conducting a survey to each object that is examined with a question guide. The results of the study stated that the compliance of managers, employees and visitors in the modern market and hospitality area was high with a value from $85 \%$ to $100 \%$. On the other hand, the compliance of managers, employees and visitors in the traditional market area of batik village, wholesaler, batik museum tourism with a compliance value of the Health protocol was from 50\% to $75 \%$. Furthermore, compliance of managers, employees and visitors in the Sari beach tourism area, open space areas, religious tourism and restaurants with a value of compliance with the Health protocol was from $20 \%$ to $60 \%$. The majority of noncompliance is due to the absence of punishments for violations of Health protocols.
\end{abstract}

Keyword: Covid-19, tourism, new normal

\section{PENDAHULUAN}

Pariwisata adalah salah satu industri kreatif yang banyak dikembangkan oleh berbagai negara, karena diyakini sebagai industri yang memiliki efek domino terhadap industri lain seperti transportasi, perhotelan, kuliner dan bisnis penunjang lain. Berkembanganya industri pariwisata juga akan menjadi daya ungkit bagi pendapatan ekonomi, pertumbuhan ekonomi dan penyerapan tenaga kerja daerah. Kota Pekalongan memiliki tempat-tempat wisata antara lain: Pantai Pasir Kencana, Pantai Slamaran, Pusat Informasi Mangrove, dan Museum Batik. Daya tarik Kota Pekalongan sebagai tempat wisata ditunjang dengan banyak sumber daya yang melekat pada perkotaan seperti: (1) Kota lama / Eks Kantor Karesidenan Pekalongan; (2) Adanya kawasan jalan tertentu yang memiliki mitologi tertentu seperti nostalgia, historis, dan heroik; (3) Monumen Juang, yang memiliki pesan edukasi historis; (4) Kuliner yang menjadi daya tarik wisata yang menarik, seperti sego megono dan soto Pekalongan; (5) Kampus atau universitas; (6) Alun-alun dan taman kota; (7) Museum Batik sebagai bagian dari wujud pelestarian batik; dan (8) Berbagai sarana penginapan dan perdagangan. Namun demikian pertumbuhan ekonomi tidak linier dengan pengembangan pariwisata di Kota Pekalongan, bahkan terjadi penurunan. Menurut data Pekalongan Dalam Angka Tahun 2019 bahwa pada tahun 2018 
jumlah wisatawan yang berkunjung ke Kota Pekalongan mengalami penurunan yang signifikan. Pada tahun 2017 jumlah wisatawan nusantara yang mengujungi obyek wisata sebanyak 137.538 orang. Sedang pada tahun 2018 berjumlah 102.070 orang. Pantai Pasir Kencana menjadi tempat wisata yang paling banyak dikunjungi dengan jumlah pengunjung 69.184 orang. Penurunan jumlah wisatawan tersebut berimbas pada pendapatan daerah. Jika pada tahun 2017 mencapai Rp.645.671.000, maka pada tahun 2018 ini hanya mencapai Rp.393.283.825, menurun Rp.252.387.175 $(39,09 \%)$. Kondisi ini diperparah dengan adanya masa pandemi Covid-19 yang sampai sekarang belum menunjukkan adanya gejala penurunan kasus wabah. Selama masa pandemi seluruh tempat wisata di Kota Pekalongan ditutup dan tidak membuka untuk pengunjung. Hal ini dilakukan untuk menurunkan atau mencegah penyebaran virus. Sementara itu bisnis perhotel, kuliner, dan pusat perbelanjaan hanya diperbolehkan menjalankan bisnis dengan skala terbatas. Masa pembatasan usaha sampai sekarang telah berjalan lebih dari 3 bulan dan jika berlangsung terus tentu saja akan mematikan aktivitas ekonomi dan akan berujung pada penurunan pendapatan masyarakat, merosotnya pertumbuhan ekonomi daerah, dan akan berujung pemutusan hubungan kerja, serta penurunan kesejahteraan masyarakat. Kondisi tersebut menjadi alasan pemerintah untuk merealisasikan skenario adaptasi kebiasaan baru atau tatanan baru beradaptasi dengan Covid-19, karena selama vaksin Covid-19 belum ditemukan masyarakat akan senantiasa hidup berdampingan dengan Covid-19. Pada masa adaptasi kebiasaan baru masing-masing sektor pariwisata dan bisnis yang terkait dengan sektor pariwisata di Kota Pekalongan harus mampu merumuskan Sistem Operasional Prosedur (SOP) yang memastikan bahwa aktivitas usaha yang akan dilakukan selama masa pandemi tetap menjamin aman para pengguna dari Covid-19 dan menentukan strategi recovery yang tepat untuk kelangsungan usahanya dengan penerimaan yang lebih rendah dibandingkan dengan masamasa sebelumnya. Berdasarkan uraian tersebut maka fokus pembahasan riset ini adalah bagaimana persiapan sektor pariwisata Kota Pekalongan dalam masa adaptasi kebiasaan baru dan bagaimanakah strategi recovery yang dilakukan untuk kelangsungan sektor wisata dalam adaptasi kebiasaan baru.

Penelitian ini mempunyai tujuan mengidentifikasi dan menganalisis kesiapan sektor pariwisata dan fasilitas pendukung pariwisata di Kota Pekalongan dalam masa adaptasi kebiasaan baru serta strategi recovery. Hal ini dilakukan untuk kelangsungan sektor wisata dalam masa adaptasi kebiasaan baru.

\section{TINJAUAN PUSATAKA}

\subsection{Kepariwisataan}

Kepariwisataan adalah keseluruhan kegiatan yang terkait dengan pariwisata dan bersifat multidimensi serta multidisiplin yang muncul sebagai wujud kebutuhan setiap orang dan negara serta interaksi antara wisatawan dan masyarakat setempat, sesama wisatawan, pemerintah, pemerintah daerah, dan pengusaha. Pembangunan kepariwisataan dapat diwujudkan melalui pelaksanaan rencana pembangunan kepariwisataan dengan memperhatikan keanekaragaman, keunikan, dan kekhasan budaya dan alam, serta kebutuhan manusia untuk berwisata. Pembangunan kepariwisataan meliputi industri pariwisata, destinasi pariwisata, pemasaran, dan kelembagaan kepariwisataan.

\subsection{Potensi dan Daya Tarik Wisata}

Potensi wisata menurut Mariotti dalam Yoeti (1983) adalah segala sesuatu yang terdapat di daerah tujuan wisata, dan merupakan daya tarik agar orang-orang mau datang berkunjung ke tempat tersebut. Daya tarik wisata menurut Cooper, dkk. (1995: 81) mengemukakan bahwa terdapat empat komponen yang harus dimiliki oleh sebuah objek wisata, yaitu: attraction, accessibility, amenity dan ancilliary.

\subsection{Konsep Adaptasi Kebiasaan Baru}

\subsubsection{Adaptasi kebiasaan baru}

Adaptasi kebiasaan baru menurut kamus Bahasa Indonesia adalah kenormalan baru. Sedangkan dalam bidang sosial dan bidang kesehatan adaptasi kebiasaan baru adalah skenario atau tatanan baru untuk mempercepat penanganan Covid-19 dalam aspek kesehatan 
dan sosial ekonomi. Adanya pandemi Covid-19 sangat mempengaruhi produktivitas sumber daya manusia di Indonesia dalam pembangunan. Tempat dan fasilitas umum merupakan area di mana masyarakat melakukan aktivitas kehidupan sosial dan berkegiatan dalam memenuhi kebutuhan hidupnya. Risiko pergerakan orang dan berkumpulnya masyarakat pada tempat dan fasilitas umum, memiliki potensi penularan Covid-19 yang cukup besar, namun demikian agar roda perekonomian tetap dapat berjalan dan krisis ekonomi dapat diatasi maka semua aktivitas kehidupan sosial dan ekonomi harus tetap berjalan sampai pandemi Covid-19 dapat segera berakhir.

\subsubsection{Protokol Transisi New Normal/} Adaptasi Kebiasaan Baru

Dalam menghadapi pandemi Covid-19, WHO menetapkan protokol menuju transisi new normal/adaptasi kebiasaan baru. Berikut 6 syarat menuju tranisisi kebiasaan baru:

a. Pemerintah bisa membuktikan bahwa transmisi virus corona sudah dikendalikan.

b. Rumah sakit atau sistem kesehatan tersedia untuk mengidentifikasi, menguji, mengisolasi, melacak kontak, dan mengkarantina pasien Covid-19, maka perlu dilakukan mitigasi dampak pandemi Covid-19 khususnya di tempat dan fasilitas umum. Masyarakat harus melakukan perubahan pola hidup dengan tatanan dan adaptasi kebiasaan yang baru agar dapat hidup produktif dan terhindar dari penularan Covid-19. Kedisiplinan dalam menerapkan prinsip pola hidup yang lebih bersih dan sehat merupakan kunci dalam menekan penularan Covid-19 pada masyarakat.

c. Risiko penularan wabah sudah terkendali terutama di tempat dengan kerentanan tinggi.

d. Langkah pencegahan di lingkungan kerja, seperti menjaga jarak, cuci tangan dan etika saat batuk.

e. Mencegah kasus impor virus corona.

f. Mengimbau masyarakat untuk berpatisipasi dan terlibat dalam transisi kebiasaan baru.

\subsubsection{Protokol Kesehatan Pencegahan Covid -19 menghadapi Kebiasaan Baru \\ Dalam menghadapi adaptasi kebiasaan} baru menuju masyarakat yang produktif dan aman terhadap Corona Virus Disease 2019 (Covid-19), diperlukan penataan penyelenggaraan berbagai kegiatan dengan prioritas kesehatan masyarakat. Pemerintah Republik Indonesia melalui KEPMENKES RI Nomor HK.01.07/MENKES/382/2020 menetapkan protokol kesehatan bagi masyarakat di tempat dan fasilitas umum dalam rangka pencegahan dan pengendalian Covid-19.

Ruang lingkup protokol kesehatan ini meliputi upaya pencegahan dan pengendalian Covid-19 di tempat dan fasilitas umum dengan memperhatikan aspek perlindungan kesehatan individu dan titik-titik kritis dalam perlindungan kesehatan masyarakat, yang melibatkan pengelola, penyelenggara, atau penanggung jawab tempat dan fasilitas umum serta masyarakat pengguna.

Peran masyarakat untuk dapat memutus mata rantai penularan Covid-19 (risiko tertular dan menularkan) harus dilakukan dengan menerapkan protokol kesehatan.

Protokol kesehatan pencegahan Covid-19 secara umum meliputi:

a. Perlindungan kesehatan individu melalui 5 M (mencuci tangan, memakai masker, menjaga jarak, menghindari kerumunan dan makan sehat dan bergizi untuk meningkatkan daya tahan tubuh)

b. Perlindungan Kesehatan Masyarakat. Dalam perlindungan kesehatan masyarakat peran pengelola, penyelenggara, atau penanggung jawab tempat dan fasilitas umum sangat penting untuk menerapkan unsur pencegahan (prevent) sebagai berikut:

1) Kegiatan promosi kesehatan (promote) dilakukan melalui sosialisasi, edukasi, dan penggunaan berbagai media informasi untuk memberikan pengertian dan pemahaman bagi semua orang, serta keteladanan dari pimpinan, tokoh masyarakat, dan melalui media mainstream. 
2) Kegiatan perlindungan (protect) antara lain dilakukan melalui penyediaan sarana cuci tangan pakai sabun yang mudah diakses dan memenuhi standar atau penyediaan handsanitizer, upaya penapisan kesehatan orang yang akan masuk ke tempat dan fasilitas umum, pengaturan jaga jarak, disinfeksi terhadap permukaan, ruangan, dan peralatan secara berkala, serta penegakan kedisplinan pada perilaku masyarakat yang berisiko dalam penularan dan tertularnya Covid-19 seperti berkerumun.

Protokol kesehatan pencegahan dan pengendalian Covid-19 di tempat dan fasilitas umum serta beberapa tempat yang mempunyaii potensi terjadinya banyak kerumunan atau ruang publik antara lain:

a. Pasar dan sejenisnya.

b. Pusat perbelanjaan / mall / pertokoan dan sejenisnya.

c. Hotel / penginapan / homestay / asrama dan sejenisnya

d. Rumah makan, café atau restoran dan sejenisnya.

e. Sarana dan kegiatan olahraga.

f. Moda transportasi.

g. Stasiun/terminal/pelabuhan/bandar udara.

\subsection{Konsep Strategi Pengembangan}

\subsubsection{Pengertian Strategi}

Menurut Chandler (2005), strategi merupakan alat untuk mencapai tujuan perusahaan dalam kaitannya dengan tujuan jangka panjang, serta prioritas alokasi sumber daya. Menurut Learned, Christensen, Andrews dan Guth (1965), strategi merupakan alat untuk menciptakan keunggulan bersaing. Dengan demikian salah satu fokus strategi adalah memutuskan apakah bisnis tersebut harus ada atau tidak ada.

\subsubsection{Manajemen Strategis}

Manajemen strategis didefinisikan sebagai seni dan pengetahuan untuk merumuskan, mengimplementasikan, dan mengevaluasi keputusan lintas fungsi yang memungkinkan organisasi dapat mencapai tujuannya. Manajemen strategis berfokus pada mengintegrasikan manajemen, pemasaran, keuangan/ akuntansi,produksi/operasi, penelitian dan pengembangan, dan sistem informasi komputer untuk mencapai keberhasilan organisasi. Tujuan manajemen strategis adalah untuk mengeksploitasi serta menciptakan berbagai peluang baru yang berbeda untuk masa mendatang dan perencanaan jangka panjang serta mencoba untuk mengoptimalkan tren-tren sekarang untuk masa datang. Manajemen strategis meliputi pengamatan lingkungan, perusahaan strategi, dan evaluasi serta pengendalian. Manajemen strategis menekankan pada pengamatan dan evaluasi peluang dan ancaman lingkungan dengan melihat kekuatan dan kelemahan perusahaan. Dapat dikatakan bahwa manajemen strategis merupakan cara untuk mengelola semua sumber daya guna mengembangkan keunggulan kompetitif jangka panjang.

\subsection{Konsep SWOT}

Analisis SWOT bertujuan untuk mengidentifikasi berbagai faktor secara sistematis untuk merumuskan suatu strategi pembangunan daerah. Sebagai sebuah konsep dalam manajemen strategik, teknik ini menekankan mengenai perlunya penilaian lingkungan eksternal dan internal, serta kecenderungan perkembangan/perubahan di masa depan sebelum menetapkan sebuah strategi. Analisis ini didasarkan pada logika yang dapat memaksimalkan kekuatan (Strengths) dan peluang (Opportunities), namun secara bersamaan dapat meminimalkan kelemahan (Weaknesses) dan ancaman (Threats).

\subsubsection{Kekuatan (Strengths)}

Kekuatan adalah sumber daya, keterampilan atau keunggulan keunggulan lain yang membedakan suatu perusahaan dengan pesaingnya. Kekuatan diambil dari internal perusahaan.

\subsubsection{Kelemahan (Weaknesses)}

Kelemahan adalah suatu keterbatasan atau kekurangan di dalam sumber daya, keterampilan dan kapabilitas yang dapat menghambat kinerja dari suatu perusahaan. Kelemahan diambil dari internal perusahaan.

\subsubsection{Peluang (Opportunities)}

Peluang adalah suatu kondisi di luar lingkungan perusahaan yang menguntungkan 
dan dapat dimanfaatkan oleh perusahaan untuk mendapatkan keuntungan.

\subsubsection{Ancaman (Threats)}

Ancaman adalah suatu kondisi di mana keadaan di luar lingkungan perusahaan dapat menjadi penghalang atau pengganggu yang menghambat kinerja perusahaan.

\section{METODE PENELITIAN}

Jenis penelitian ini adalah penelitian deskripsi yaitu berupaya untuk memperoleh hasil deskripsi yang lengkap dan akurat dari suatu situasi (Boyd, Wastfall, Stasch, 1989). Metode yang digunakan dalam penelitian ini adalah metode survei yaitu suatu metode penyelidikan yang diadakan untuk memperoleh fakta-fakta dari gejala-gejala yang ada dan mencari keterangan-keterangan secara faktual, baik tentang institusi sosial, ekonomi, atau politik dari suatu kelompok ataupun suatu daerah (Nazir, 1988: 65).

Lokasi penelitian adalah wilayah Kota Pekalongan meliputi Dinas Pariwisata, Kebudayaan, Kepemudaan dan Olahraga Kota Pekalongan, lokasi wisata dan usaha penunjang kepariwisataan seperti perhotelan, pusat perdagangan, dan trasportasi massal.

Data yang digunakan meliputi data primer dan data sekunder. Adapun teknik pengumpulan data menggunakan pengamatan secara langsung dan wawancara terhadap pengelola, karyawan, dan pengunjung. Obyek amatan meliputi: Obyek Wisata Pasir Kencana, Obyek Wisata Pantai Slamaran, Obyek Wisata Museum Batik Pekalongan, Pusat Informasi Mangrove, tempat wisata religi, serta tempat-tempat usaha penunjang pariwisata seperti hotel, restoran, pusat grosir, mall, dan jasa transportasi.

Populasi dalam penelitian ini adalah seluruh tempat pariwisata dan fasilitas pendukung pariwisata di Kota Pekalongan. Sampel penelitian ini adalah penentu kebijakan pada Dinas Pariwisata, Kebudayaan, Kepemudaan dan Olahraga, Dinas Perdagangan, Koperasi dan UKM, pengelola, karyawan, dan pengunjung. Sampel diambil sebanyak 200 responden.

Teknik analisa data yang digunakan dalam penelitian ini adalah analisis data kualitatif. Menurut Miles dan Huberman (1992), terdapat tiga alur dalam menganalisa data kualitatif yaitu mencakup : 1) Reduksi data, yang berarti bahwa dilakukannya suatu kegiatan untuk merangkum atau meringkas dan menyederhanakan data-data yang diperlukan dan mengabaikan data yang tidak diperlukan; 2) Penyajian data, tahapan ini merupakan tahap di mana penulis menyajikan suatu uraian singkat dari sekumpulan informasi yang pada akhirnya akan memberi kemungkinan penulis untuk menarik kesimpulan; dan, 3) penarikan kesimpulan/ verifikasi, merupakan tahap akhir di mana peneliti mulai mencari arti benda-benda atau hubungan sebab akibat dari suatu fenomena.

Pada penelitian ini akan dilakukan analisa dari data pengkajian awal di seluruh lokasi penelitian sehingga diketahui data tentang kondisi pelaksanaan pencegahan Covid-19 dengan tatanan kehidupan baru (kebiasaan baru), serta hambatan dan solusinya. Analisis menggunakan SWOT untuk mengetahui peluang dan hambatan dalam pelaksanaan recovery pariwisata di Kota Pekalongan.

\section{HASIL PENELITIAN}

\subsection{Perhotelan}

Hasil survei ketersediaan sarana protokol kesehatan pada perhotelan $92 \%$ terpenuhi, hanya sarana pertolongan pertama yang belum tersedia. Pengelola hotel mematuhi protokol kesehatan dalam pencegahan Covid-19, hanya $15 \%$ yang tidak dipatuhi yaitu melarang anak $<9$ tahun atau comorbid untuk berkunjung, survei kesehatan secara rutin untuk karyawan, serta pelaksanaan protokol kesehatan secara terus menerus, juga pengaturan jarak meja karyawan. Pelaksanaan protokol kesehatan oleh karyawan menggambarkan 100\% karyawan hotel melaksanakan protokol kesehatan dalam pencegahan Covid-19 sesuai standar prosedur operasional.

\subsection{Pasar Batik Grosir dan Kampung Batik \\ Pesindon}

Berdasarkan survei ketersediaan sarana protokol kesehatan pada pasar batik tidak ada sarana pertolongan pertama bila ada yang menunjukkan gejala Covid-19, 100\% tidak mempunyai standar prosedur protokol kesehatan, tidak ada sanksi bila ada pelanggaran, dan keberlangsungan sosialisasi pencegahan Covid-19 belum dilaksanakan di 
semua tempat. Sebagian besar pengelola tidak mematuhi protokol kesehatan, hanya mengatur sirkulasi terbuka, menyedikan cuci tangan dan menyediakan promosi protokol pencegahan Covid-19.

Tabel 1 Persentase Pelaksanaan Protokol Kesehatan di Pasar Grosir Setono dan Kampung Batik

\begin{tabular}{lc}
\hline \multicolumn{1}{c}{ Lokasi } & $\begin{array}{c}\text { Pelaksanaan } \\
\text { Protokol Kesehatan }\end{array}$ \\
\hline Pasar Grosir Setono & $20 \%$ \\
Kampung Batik Pesindon & $35 \%$ \\
Kampung Batik Kauman & $35 \%$ \\
\hline
\end{tabular}

Dari tabel di atas digambarkan bahwa protokol kesehatan yang dilakukan di Pasar Grosir Setono hanya sebesar 20\%, Kampung Batik Pesindon sebesar 35\%, dan Kampung Batik Kauman sebesar 35\%. Hasil survey pada karyawan dalam melaksanakan semua protokol kesehatan menggambarkan karyawan di Grosir Setono mayoritas tidak memahami pencegahan Covid-19 dan protokol kesehatan, tidak menyediakan APD dan hanya sebagian yang menggunakan masker. Dari semua item protokol kesehatan yang dilaksanakan di Grosir Setono 11\%, di Kampung Batik Pesindon 5\%, dan di Kampung Batik Kauman $5 \%$. Mayoritas pengunjung tidak tahu protokol pencegahan Covid-19, Sebagian besar membawa APD masker, tetapi hanya 33\% yang memakai masker.

\subsection{Toko Modern}

Pada toko modern ditemukan sebagian (20\%) protokol kesehatan tidak dilaksanakan oleh pengelola. Kegiatan protokol kesehatan yang di mall tidak dijalankan oleh pengelola adalah larangan anak di bawah usia 9 tahun dan lansia/comorbid berkunjung ke mall, dan survei kesehatan karyawan secara rutin tidak dilakukan.

Tabel 2 Hasil Pelaksanaan Protokol Kesehatan di Toko Modern / Mall

\begin{tabular}{|c|c|}
\hline Protokol Kesehatan & Hasil \\
\hline Mencuci tangan sebelum dan & $40 \%$ \\
\hline sesudah berkunjung & dilaksanakan \\
\hline $\begin{array}{l}\text { Larangan masuk anak } 9 \text { tahun } \\
\text { ke bawah }\end{array}$ & $\begin{array}{c}\text { Tidak } \\
\text { dilaksanakan }\end{array}$ \\
\hline Larangan & Tidak \\
\hline comorbid & dilaksanakan \\
\hline $\begin{array}{l}\text { Menjaga jarak dan tidak } \\
\text { menyentuh wajah }\end{array}$ & $\begin{array}{c}60 \% \\
\text { dilaksanakan }\end{array}$ \\
\hline
\end{tabular}

Hasil survei menggambarkan semua karyawan (100\%) sudah melaksanakan protokol kesehatan untuk mencegah penularan Covid-19. Mayoritas sudah mematuhi dan melaksanakan protokol kesehatan untuk mencegah penularan Covid-19, namun pengunjung $100 \%$ tidak segera mandi sebelum kontak dengan keluarga, $60 \%$ tidak mencuci tangan sebelum dan sesudah berkunjung, $40 \%$ pengunjung tidak menjaga jarak dan menyentuh wajah.

\subsection{Tempat Wisata}

Sebagian besar sarana pencegahan penularan Covid-19 dan protokol kesehatan disediakan oleh pengelola di Museum Batik, sedangkan di Pantai Sari 50\% pengelola belum menyediakan sarana pencegahan Covid-19 sesuai protokol kesehatan. Kedua lokasi wisata belum tersedia sarana pertolongan pertama untuk penderita Covid-19, sedangkan di Pantai Sari juga belum ada SPO pencegahan Covid-19, dan keberlangsungan sosialisasi. Pada Museum Batik Pekalongan sebagian (20\%) protokol kesehatan tidak dilaksanakan oleh pengelola dan di Pantai Sari (40\%), kegiatan protokol kesehatan, yang tidak dilaksanakan di kedua kawasan wisata pengaturan jarak meja kerja dan penambahan suplemen untuk karyawan. Sebagian besar karyawan (70\%) sudah melaksanakan protokol kesehatan untuk mencegah penularan Covid-19. Namun ada beberapa protokol kesehatan yang belum dilaksanakan yaitu menghindari menyentuh wajah, menggunakan pakaian seragam, jaga jarak dan segera mandi sebelum kontak dengan anggota keluarga yang lain. Menggambarkan $50 \%$ pengunjung sudah mematuhi dan melaksanakan protokol kesehatan untuk mencegah penularan Covid-19, namun pengunjung $100 \%$ tidak segera mandi sebelum kontak dengan keluarga, $60 \%$ tidak mencuci tangan sebelum dan sesudah berkunjung, $40 \%$ pengunjung tidak menjaga jarak dan menyentuh wajah.

\subsection{Kawasan Terbuka Publik}

Sedangkan ketersediaan sarana protokol kesehatan di kawasan rekresai ruang terbuka sebanyak $50 \%$ sarana pencegahan penularan Covid-19 dan protokol kesehatan disediakan oleh pengelola di kawasan rekreasi ruang terbuka Mataram, sedangkan di Alun-alun 
hanya tersedia media promosi protokol pencegahan Covid-19. Kawasan rekreasi ruang terbuka Mataram $45 \%$ protokol kesehatan dilaksanakan oleh pengelola, sedangkan di Alun-alun $10 \%$ protokol kesehatan dilaksanakan oleh pengelola. Menggambarkan kondisi karyawan di Mataram (67\%) sudah melaksanakan protokol kesehatan untuk mencegah penularan Covid-19. Sedangkan di kawasan terbuka Alun-alun protokol kesehatan yang dilakukan karyawan (54\%), yang belum dilakukan oleh karyawan sering mencuci tangan dan menyentuh wajah, menjaga jarak $(20 \%)$. Menggambarkan sebagian besar belum mematuhi dan melaksanakan protokol kesehatan untuk mencegah penularan Covid-19, pengunjung tidak mengukur suhu badan sebelum berkunjung, pengunjung $100 \%$ tidak segera mandi sebelum kontak dengan keluarga, $60 \%$ tidak mencuci tangan sebelum dan sesudah berkunjung, $40 \%$ pengunjung tidak menjaga jarak dan menyentuh wajah.

\subsection{Terminal dan Stasiun}

Protokol kesehatan disediakan oleh pengelola di terminal maupun stasiun, sedangkan yang belum dilaksanakan adalah sanksi pelanggaran protokol kesehatan belum dilaksanakan untuk pencegahan Covid-19, baik di terminal maupun stasiun pelaksanaan protokol kesehatan oleh pengelola di terminal $45 \%$, dan di stasiun $60 \%$ protokol kesehatan dilaksanakan oleh pengelola. Sedangkan ratarata pengunjung belum mematuhi dan melaksanakan protokol kesehatan untuk mencegah penularan Covid-19 secara lengkap, terutama dalam mencuci tangan, menghindari menyentuh wajah dan menjaga jarak serta pengunjung $100 \%$ tidak segera mandi sebelum kontak dengan keluarga, $60 \%$ tidak mencuci tangan sebelum dan sesudah berkunjung, $40 \%$ pengunjung tidak menjaga jarak dan menyentuh wajah.

\subsection{Rumah Makan, Café atau Restoran}

Sarana pencegahan penularan Covid-19 dan protokol kesehatan disediakan oleh pengelola di kawasan rumah makan Bang Dul dan Masduki Alun-alun hanya cuci tangan dan media promosi protokol pencegahan Covid-19. Sarana yang lainnya belum tersedia. Protokol Kesehatan yang dilakukan karyawan sebagian yaitu (18\%) . Sedangkan pengunjung belum melaksanakan protokol kesehatan tentang pencegahan Covid-19, pengunjung mayoritas sudah membawa masker tetapi hanya $40 \%$ yang memakai. Tidak ada pengukuran suhu (100\%), menghindari menyentuh wajah (100\%) jaga jarak tidak dilakukan

\subsection{Wisata Religi}

Sebanyak 28,5\% sarana pencegahan penularan Covid-19 dan protokol kesehatan disediakan oleh pengelola di kawasan wisata religi, sarana yang disediakan sarana cuci tangan dan promosi kesehatan. Pelaksanaan protokol kesehatan di kawasan wisata religi Habib Ahmad dan di kawasan Pengajian Kliwonan 20\%. Mayoritas pengunjung belum mematuhi melaksanakan protokol kesehatan untuk mencegah penularan Covid-19, Baik di kawasan wisata religi Habib Ahmad maupun kawasan Pengajian Kliwonan.

Analisis SWOT dilakukan pada masingmasing tempat yang menjadi obyek penelitian dan dihasilkan strategi recovery kepariwisataan di masa adaptasi kehidupan baru sebagaimana berikut :

Tabel 3 Strategi Recovery Kepariwisataan di Masa Adaptasi Kehidupan Baru

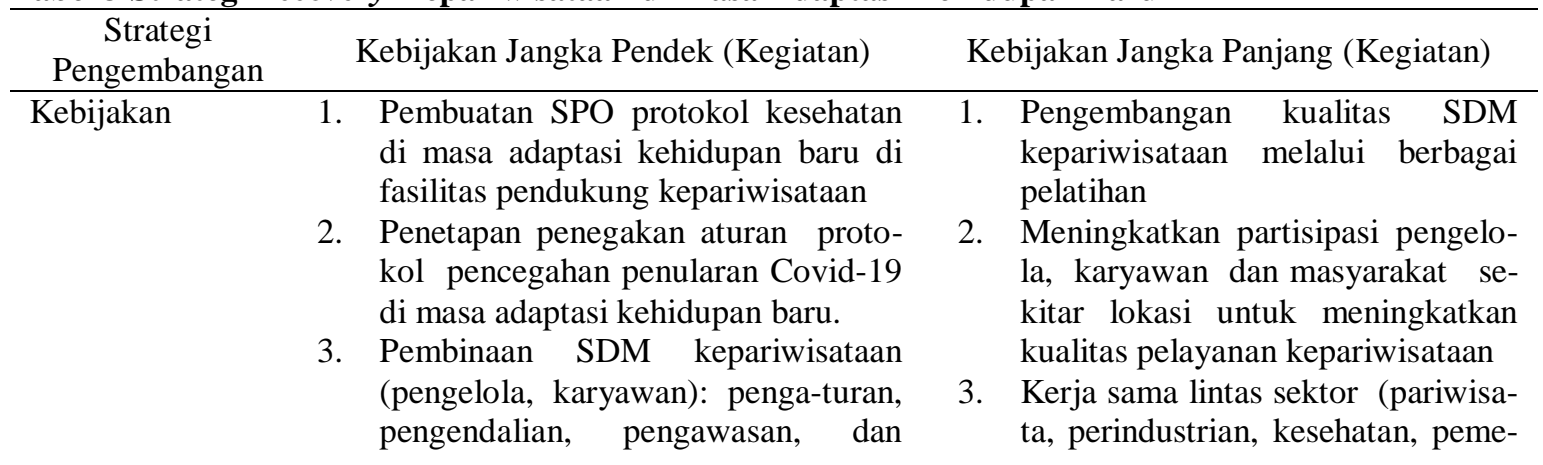




\begin{tabular}{|c|c|c|}
\hline $\begin{array}{c}\text { Strategi } \\
\text { Pengembangan }\end{array}$ & Kebijakan Jangka Pendek (Kegiatan) & Kebijakan Jangka Panjang (Kegiatan) \\
\hline \multirow[b]{2}{*}{$\begin{array}{l}\text { Fasilitas dan } \\
\text { Aktivitas }\end{array}$} & $\begin{array}{l}\text { penerapan sanksi. } \\
\text { 4. Pembinaan bagi para pengunjung } \\
\text { kepariwisataan, pengaturan, peng- } \\
\text { endalian, pengawasan, dan penera- } \\
\text { pan sanksi }\end{array}$ & $\begin{array}{l}\text { rintah daerah, swasta) dalam pe- } \\
\text { nyediaan sarana dan pelaksanaan } \\
\text { protokol kesehatan } \\
\text { 4. Penetapan dan sosialisasi Perda } \\
\text { tentang kepariwisataan di masa } \\
\text { adaptasi kehidupan baru }\end{array}$ \\
\hline & $\begin{array}{l}\text { 1. Peningkatan fasilitas-fasilitas pen- } \\
\text { cegahan Covid-19 pada sektor } \\
\text { pendukung kepariwisataan secara } \\
\text { bertahap hingga memenuhi standar } \\
\text { 2. Peningkatan kerja sama dengan } \\
\text { stakeholder dan lintas sektor } \\
\text { 3. Penyediaan sarana informasi } \\
\text { pencegahan Covid-19 di area } \\
\text { strategis. } \\
\text { 4. Pembentukan tim gugus Covid-19 di } \\
\text { masing masing sektor dan } \\
\text { terkoordinir oleh dinas kepari- } \\
\text { wisataan dan dinas kesehatan } \\
\text { 5. Sosialisasi protokol kesehatan di } \\
\text { sektor kepariwisataan secara rutin } \\
\text { Penegakan aturan dan pemberian } \\
\text { sanksi pelanggaran SPO protokol } \\
\text { kesehatan. }\end{array}$ & $\begin{array}{l}\text { 1. Tersedia fasilitas kesehatan di } \\
\text { semua sektor kepariwisataan. } \\
\text { 2. Terbentuk budaya perilaku hidup } \\
\text { bersih dan sehat di sektor kepari- } \\
\text { wisataan oleh pengelola, karyawan } \\
\text { dan pengunjung. } \\
\text { 3. Tersedia layanan pence-gahan dan } \\
\text { pertolongan pertama Kesehatan } \\
\text { secara terpadu lintas sektor kepari- } \\
\text { wisataan. } \\
\text { 4. Dukungan perda dalam penegakan } \\
\text { aturan dan sanksi pelanggaran } \\
\text { protokol kesehatan di sektor } \\
\text { kepariwisataan }\end{array}$ \\
\hline
\end{tabular}

\section{SIMPULAN DAN SARAN}

\subsection{Simpulan}

Dari hasil penelitian yang sudah dilakukan pada beberapa kawasan yang mendukung pariwisata di Kota Pekalongan dapat disimpulkan sebagai berikut :

a. Kepatuhan pengelola, karyawan dan pengunjung di kawasan pasar modern dan perhotelan tinggi dengan nilai antara $85 \%$ sampai $100 \%$. Hal ini menunjukkan bahwa pengelola menyadari pentingnya pencegahan Covid-19 dan menjaga standar pelayanaan agar pengunjung relatif aman menginap di hotel pada era adaptasi kebiasaan baru.

b. Kepatuhan pengelola, karyawan dan pengunjung di kawasan pasar tradisional, kampung batik, pasar grosir, wisata museum batik dengan nilai kepatuhan pada protokol kesehatan antara 50\% sampai $75 \%$. Kepatuhan pada tempat tersebut relatif cukup namun perlu kesadaran individu dalam beradaptasi dengan kebiasaan baru. c. Kepatuhan pengelola, karyawan dan pengunjung di kawasan Obyek Wisata Pantai Sari, wilayah ruang terbuka, wisata religi dan rumah makan dengan nilai kepatuhan pada protokol kesehatan antara $20 \%$ sampai $60 \%$. Nilai ini relatif rendah sehingga perlu sosialisasi, himbauan atau paksaan dalam mematuhi 5M untuk saling menjaga satu sama lain.

d. Hasil tabulasi data observasi maupun wawancara mayoritas kepatuhan karena tidak ada sanksi terhadap pelanggaran protokol kesehatan.

\subsection{Saran}

a. Perlu ditegakkan aturan dan disiplin pencegahan dan penyebaran Covid-19 tidak hanya pada tataran regulasi tetapi juga implementasi dalam rangka pencegahan penyebaran Covid-19, misalnya operasi masker dan penyediaan tempat cuci tangan di tempat-tempat wisata, kuliner, pasar, grosir, rumah makan dan tempat-tempat umum lainnya. 
b. Perlu petugas rutin yang menjalankan operasi kepatuhan terhadap pencegahan Covid-19.

\section{REFERENSI}

Boyd. H. W., Jr., Westfall. R., dan Stasch.S.F, "Marketing Reaserch: Text and Cases", Irwin, Boston, 1989.

Budiyanti, Eka. (2020). Dampak Virus Corona Terhadap Sektor Perdagangan dan Pariwisata Indonesia. Jakarta : Pusat Penelitian Badan Keahlian DPR RI dalam Jurnal Bidang Ekonomi dan Kebijakan Publik, Info Singkat, Kajian Singkat Terhadap Isu Aktual dan Strategis Vol. XII No.4/II/Puslit/Februari/2020

Cooper, John Fketcher, David Gilbert and Stephen Wanhill. (1995). Tourism, Principles and Practice. London: Logman.

Kementerian Kesehatan RI. (2020). Pedoman Pencegahan dan Pengedalian Coronavirus Disease (COVID-19) Revisi ke-3. Jakarta : Kementerian Kesehatan RI

Kementerian Kesehatan RI. (2020). Pedoman Pencegahan dan Pengendalian Coronavirus Disease (COVID-19). Jakarta : Direktorat Jenderal Pencegahan dan Pengendalan Penyakit (P2P).

Keputusan Menteri Kesehatan RI. (2020). Protokol Kesehatan Bagi Masyarakat di
Tempat dan Fasilitas Umum Dalam Rangka Pencegahan dan Pengendalian Corona Virus Disease 2019 (COVID-19). Jakarta : Menteri Kesehatan RI

Nazir. M. 1988. Metodologi Penelitian. Jakarta: Ghalia Indonesia

Rangkuti F. 2009. Analisis SWOT Teknik Membedah Kasus Bisnis. Jakarta: PT Gramedia Pustaka Utama. 187 hlm.

Sabana, Choliq, dkk. (2019). Analisis Potensi dan Strategi Pengembangan Objek Wisata Pantai Pasir Kencana Kota Pekalongan. Pekalongan : Dewan Riset Daerah Kota Pekalongan

Tim Komunikasi Publik Dinkominfo Kota Pekalongan. (2020). Antisipasi Penyebaran Corona, Pemkot Tutup Sementara Obyek Wisata. Pekalongan : Website Resmi Pemerintah Kota Pekalongan diakses pada 18 Maret 2020. https://pekalongankota.go.id/

Undang-Undang Republik Indonesia No.10. (2009). Kepariwisataan. Jakarta : Menteri Hukum dan Hak Asasi Manusia

Yoeti, Oka A. 1983. Perencanaan dan Pengembangan Pariwisata. Jakarta: PT. Pradnya Paramita. 